\title{
DEVELOPMENT AND DETERMINATION OF VALIDATION PARAMETERS FOR THE HPLC METHOD OF THYMOL QUANTIFICATION IN "KALINOL PLUS" SYRUP
}

\author{
T.A.Suleimanov, E.Z.Balaeva, E.Yu.Akhmedov \\ Azerbaijan Medical University \\ National University of Pharmacy \\ Key words: validation; "Kalinol plus" syrup; thymol; HPLC
}

The HPLC method of thymol quantification has been developed for the combined medicine - "Kalinol plus" syrup (produced by "Azerpharm LTD"), which consists of the brotherwort (Thymus serpyllum) extract, sugar syrup, potassium bromide and $80 \%$ ethanol. The optimal conditions for quantitative determination of thymol in "Kalinol plus" have been found when carrying out the analysis under different conditions. They are: the flow rate $-1 \mathrm{~mL} / \mathrm{min}$, the temperature $-30^{\circ} \mathrm{C}$, the volume of injection $-10 \mu \mathrm{L}$, the detection wavelength $-274 \mathrm{~nm}$, the type of stationary phase - Zorbax SB-C18 Ø4.6×250 mm, $5 \mu \mathrm{m}$, and the mobile phase composition (the mixture of water and acetonitrile (50:50) in the isocratic elution mode), the mass of the sample to be analysed $-1.0 \mathrm{~g}$, the time of analysis - $15 \mathrm{~min}$. It has been found that the analyte peak on the chromatogram is well separated from the peaks of the excipients and other components of the active substance. The validation characteristics of the method proposed have been studied. According to the results obtained the procedure developed is characterised by the acceptable linearity $\left(b=1.037, a=-5.587, R S D_{0}=1.715, R_{c}=0.9959\right)$, accuracy $(\delta=0.16)$ and precision $\left(\Delta_{z}=1.54\right)$ in the range of the method application $(70-130 \%$ of the nominal concentration). Small changes in the flow rate (from $0.8 \mathrm{~mL} / \mathrm{min}$ to $1.2 \mathrm{~mL} / \mathrm{min}$ ), temperature (from $27^{\circ} \mathrm{C}$ to $33^{\circ} \mathrm{C}$ ) and the mobile phase composition (from (47:53) to (47:53) ratio) insignificantly affect the values of the symmetry factor of the principal peak, relative standard deviation and the number of theoretical plates. The results of studying stability indicate that the solution to be analysed may be chromatographed within 1 day without losses in accuracy and precision. According to the results the method can be recommended for use in the analysis of "Kalinol plus" syrup.

"Kalinol plus" syrup (the State registration number LC No.15-00336) produced by “Azerpharm LTD" plant consists of the brotherwort (Thymus serpyllum) extract (12 parts), sugar syrup (82 parts), potassium bromide (1 part) and $80 \%$ ethanol (5 parts). In medical practice it is used as a mucolytic and expectorant medicine in acute and chronic inflammation of the respiratory tract [5].

The main active components of the syrup are the thyme extract and potassium bromide.

It is known that species of the thyme genus (Thymus) are used with different purposes in medicine all over the world; and such active natural compounds as thymol and carvacrol are mainly in the composition of the raw material. As for its antiseptic activity thymol exceeds phenol by 30 times, and its toxicity is less by 4 times than that of phenol [6-8]. Most medicines with the thyme extract or essential oil of thyme are standardized not only by the total amount of essential oil, but also by the thymol or carvacrol content [2].

Currently, only identification and quantitative determination of potassium bromide is carried out with the purpose of the quality control for "Kalinol plus" medicine, but it is insufficient. Thus, there is the necessity to develop the modern procedure for quantitative determination of thymol, being the main active ingredi- ent of "Kalinol plus" syrup, and to validate the method developed.

In spite of a wide application of the gas chromatography method for the analysis of essential oils the direct quantification of thymol and carvacrol in the composition of different dosage forms by this method is unacceptable $[3,9,10]$. Owing to the mentioned above application the method of HPLC for quantifying the individual components in plant medicines with the multicomponent composition acquires the exceptional significance.

It is known that currently at the stages of drug registration and re-registration the validation carrying out for analytical procedures is one of the main requirements of the international regulating agency $[1,4,11]$.

The aim of our paper is to develop and determine validation parameters for the procedure of thymol quantitative determination by the method of HPLC in "Kalinol plus" medicine produced in Azerbaijan.

\section{Materials and Methods}

Reagents and chemicals. Thymol reference standard $(R S)$ was obtained from KRKA (Slovenia), batch UG1456; acetonitrile hypergrade for LC-MS LiChrosolv ${ }^{\circledR}$ (batch I674930308) was purchased from Merck Millipore Corporation (USA). 
Instrumentation and chromatographic conditions. The HPLC-UV analysis was performed using an Agilent-1100 high pressure liquid chromatograph (USA); The Agilent ChemStation software (Agilent, USA) was used for integration and processing of chromatograms. The HPLC column of $\varnothing 4.6 \times 250 \mathrm{~mm}$ and the reversed phase Zorbax SB-C18, $5 \mu \mathrm{m}$ (Agilent, USA) were used as the analytical system. The analysis was carried out at $30^{\circ} \mathrm{C}$ and the flow rate of $1 \mathrm{~mL} / \mathrm{min}$. The mobile phase was the mixture of water and acetonitrile (50:50) degased using an ultrasonic bath, and it was run in the isocratic elution mode. The volume of injection was $10 \mu \mathrm{L}$. The time of analysis was $15 \mathrm{~min}$. Detection was performed at the wavelength of $274 \mathrm{~nm}$.

The mobile phase was used as the blank-solution.

The solvent for analysis was prepared as the mixture of water and acetonitrile (20:80).

Preparation of the matrix. Sugar syrup, potassium bromide and $80 \%$ ethanol were mixed according to the composition of "Kalinol plus" medicine for preparation of the matrix.

Preparation of the model mixtures. The matrix $(500.0000 \mathrm{~g})$ and thymol $R S(0.0350 ; 0.0500 ; 0.0650 \mathrm{~g})$ were mixed for preparation of the model mixtures.

Preparation of the solution to be analysed. Place $1.0000 \mathrm{~g}$ of "Kalinol plus" syrup (or matrix and model mixture) in a $25.0 \mathrm{~mL}$ volumetric flask, add $20 \mathrm{~mL}$ of the solvent and shake till complete dissolution, then degas the solution using an ultrasonic bath for $5 \mathrm{~min}$, and dilute with the solvent to the volume; mix the solution and centrifuge for $10 \mathrm{~min}$ at $10000 \mathrm{rpm}$; use the supernatant for chromatographing.

Preparation of the solution with the active substance. Place $0.1265 \mathrm{~g}$ of the brotherwort extract in a $25.0 \mathrm{~mL}$ volumetric flask, add $20 \mathrm{~mL}$ of the solvent and shake till complete dissolution, then degas the solution using an ultrasonic bath for $5 \mathrm{~min}$, and dilute with the solvent to the volume; mix the solution and centrifuge for $10 \mathrm{~min}$ at $10000 \mathrm{rpm}$; use the supernatant for chromatographing.

Preparation of the solution RS. Place $0.0400 \mathrm{~g}$ of thymol $R S$ in a $100.0 \mathrm{~mL}$ volumetric flask, add $20 \mathrm{~mL}$ of the solvent and shake till complete dissolution, dilute with the solvent to the volume. Take the aliquot of $1.00 \mathrm{~mL}$ of the solution obtained and place in a $100.0 \mathrm{~mL}$ volumetric flask, dilute with the solvent to the volume $(4 \mu \mathrm{g} / \mathrm{mL})$.

Chromatographic system suitability. The results obtained were accepted as valid if the following requirements were met:

- the symmetry factor of the principal peak should be between 0.8 and 1.5 ;

- the maximal permitted relative standard deviation for 5 replicate injections of the reference solution did not exceed $1.10 \%$;

- the number of theoretical plates should be $>1500$.

\section{Validation parameters}

The procedure was developed and validated using the method of standard.

For specificity evaluation the matrix and model mixture corresponding to the point of $130 \%$ (prepared according to the procedure), the solution with the active substance, and the blank-solution were analysed.

For linearity studies 5 solutions of thymol $R S$ with the exactly known concentrations in the range of $70-130 \%$ from the nominal one were prepared. All calculations were made using the normalized coordinates. The results obtained were processed by the method of linear regression analysis.

For accuracy and precision verification 3 model mixtures with the exactly known thymol content (concentrations were 70,100 and $130 \%$ from the nominal one) were prepared. For each model mixture 3 parallel analyses were performed, and the values of the systematic error (for accuracy), as well as the confidence interval (for precision) were calculated.

Robustness verification was made by analysing the model mixtures under different chromatographic conditions. The changes of such conditions were the following:

- the flow rate was within $\pm 20 \%$ from the mentioned in the procedure of analysis (from $0.8 \mathrm{~mL} / \mathrm{min}$ to $1.2 \mathrm{~mL} / \mathrm{min})$;

- the temperature was within $\pm 10 \%$ from the mentioned in the procedure of analysis (from $27^{\circ} \mathrm{C}$ to $33^{\circ} \mathrm{C}$ );

- the mobile phase composition was from (47:53) to 47:53) ratio for the mixture of water and acetonitrile.

The parameters for testing the chromatographic system suitability were determined and assessed.

Stability of the solution was determined by comparing the content of thymol in the solution to be analysed using the same solution $R S$ within 1 day.

\section{Results and Discussion}

The optimal conditions of the thymol quantitative determination in "Kalinol plus" syrup have been found in the analysis carrying out under different conditions such as flow rate, temperature, volume of injection, detection wavelength, type of stationary phase and mobile phase composition, mass of the sample to be analysed.

Validation parameters for the analytical procedure have been determined according to the requirements of the corresponding guidances $[9,10,11]$.

Specificity. The chromatograms of the solution with the active substance, model mixture, thymol $R S$ and "Kalinol plus" syrup are presented in Fig. 1.

It has been found that the analyte peak on the chromatogram is well separated from the peaks of the excipients and other components of the active substance.

Range. The active substance of "Kalinol plus" syrup is of the plant origin, and the thymol content in the medicine may vary in the wide range. Therefore, the range of the method application has been chosen as $70-130 \%$ from the nominal concentration. The content of thymol in the medicine accepted as $100 \%$ is $0.1 \mathrm{mg} / \mathrm{g}$.

Linearity. According to the results obtained (Fig. 2, Tab. 1) the procedure developed is characterised by the acceptable linearity in the range of the method application (70-130\%).

Accuracy and precision. The results of determining accuracy and precision are presented in Tab. 2; they confirm that the procedure developed satisfies the requirements. 


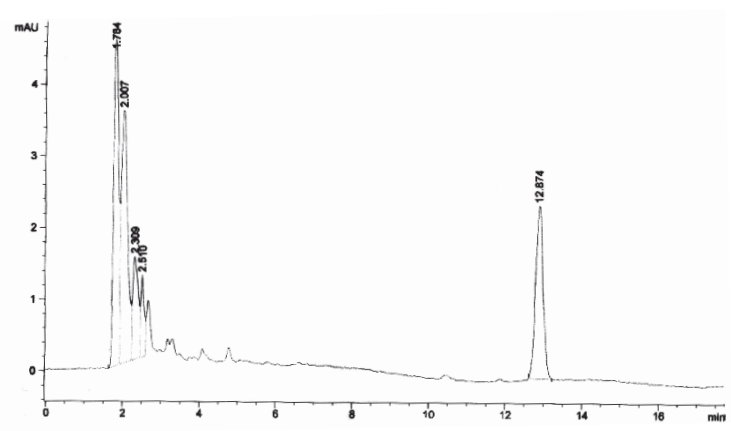

a

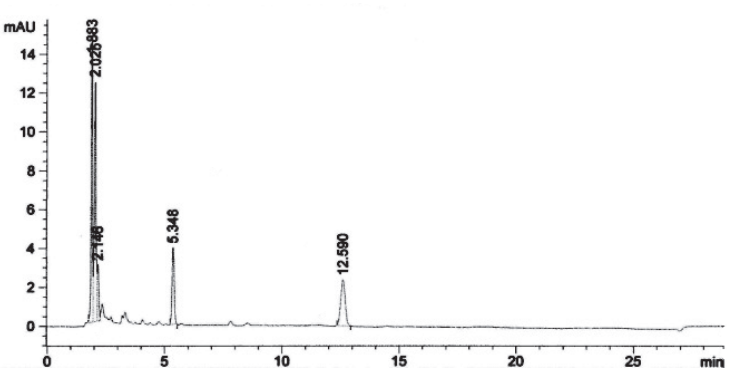

C

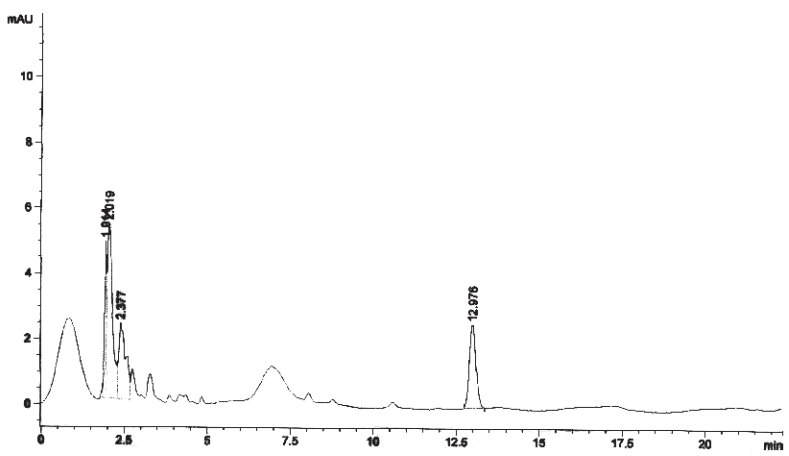

$b$

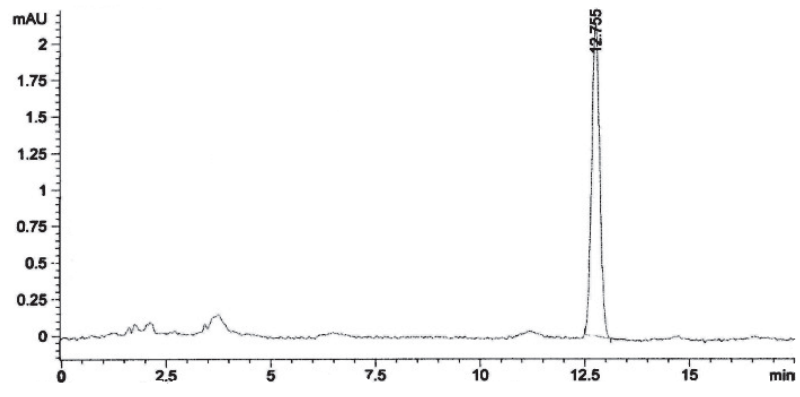

$d$

Fig. 1. The chromatograms of the solution with the active substance $(a)$, model mixture $(b)$, thymol $R S(c)$ and "Kalinol plus" syrup $(d)$.

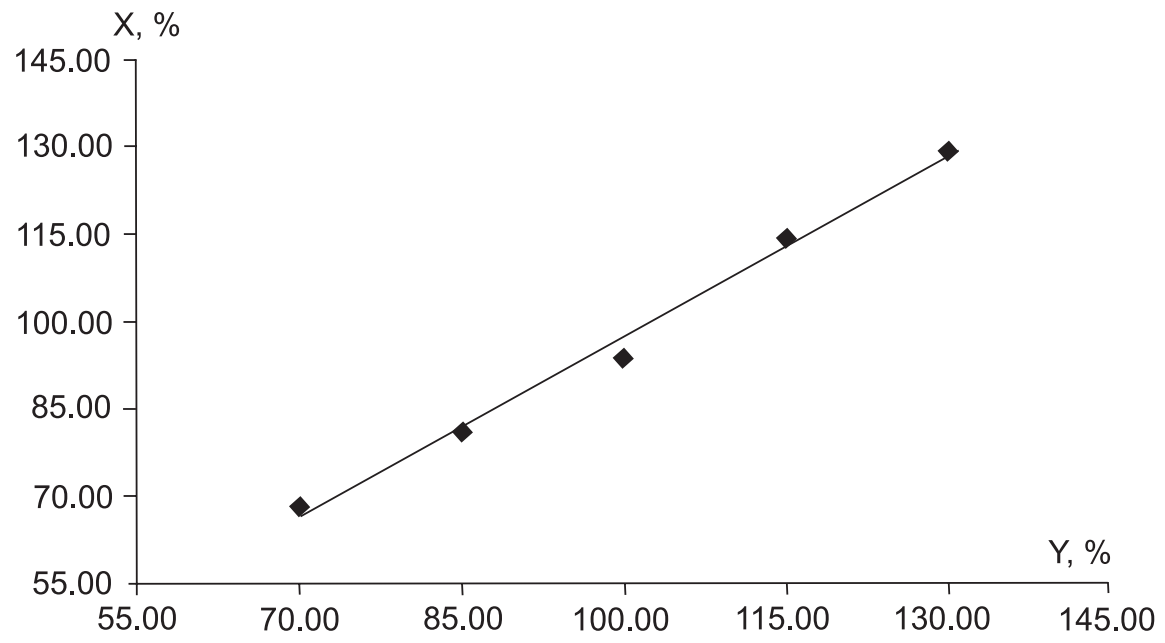

Fig. 2. The linear dependence of the peak area on the concentration of thymol solutions in the normalized coordinates.

Table 1

The linearity characteristics for the procedure of thymol quantitative determination

\begin{tabular}{|l|c|}
\hline \multicolumn{1}{|c|}{ Parameter } & Value \\
\hline Slope $b$ & 1.037 \\
\hline Standard deviation for slope $s_{b}$ & 0.054 \\
\hline Absolute term $a$ & -5.587 \\
\hline Standard deviation for absolute term $s_{a}$ & 5.476 \\
\hline Rest standard deviation $R S D_{0}$ & 1.715 \\
\hline Correlation coefficient $R_{c}$ & 0.9959 \\
\hline
\end{tabular}


Table 2

The results of accuracy and precision verification for the procedure of thymol quantitative determination

\begin{tabular}{|c|c|c|c|c|}
\hline $\begin{array}{l}\text { The thymol content in } \\
\text { the model mixture } \\
C_{i}\left(C_{s t}=4 \mu \mathrm{g} / \mathrm{mL}\right)\end{array}$ & $\begin{array}{l}\text { The content in } \% \text { to } \\
\text { the standard value } X_{i}\end{array}$ & $\begin{array}{l}\text { The peak area } \\
S_{i}\left(S_{s t}=28.217\right)\end{array}$ & $\begin{array}{l}\text { The thymol content } \\
\text { found in } \% \text { to the } \\
\text { standard peak area } Y_{i}\end{array}$ & $Z_{i}=\frac{Y_{i}}{X_{i}} \cdot 100 \%$ \\
\hline \multirow[t]{3}{*}{ 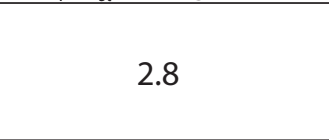 } & \multirow{3}{*}{70.00} & 19.542 & 69.26 & 98.94 \\
\hline & & 19.651 & 69.64 & 99.49 \\
\hline & & 19.812 & 70.21 & 100.30 \\
\hline \multirow{3}{*}{4.0} & \multirow{3}{*}{100.00} & 27.944 & 99.03 & 99.03 \\
\hline & & 28.534 & 101.12 & 101.12 \\
\hline & & 28.292 & 100.27 & 100.27 \\
\hline \multirow{3}{*}{5.2} & \multirow{3}{*}{130.00} & 37.101 & 131.48 & 101.14 \\
\hline & & 36.958 & 130.98 & 100.75 \\
\hline & & 36.815 & 130.47 & 100.36 \\
\hline \multicolumn{4}{|r|}{ Mean $\bar{Z}$} & 100.16 \\
\hline \multicolumn{4}{|c|}{ Relative standard deviation $R S D_{z}$} & 0.83 \\
\hline \multicolumn{4}{|c|}{ Confidence interval $\Delta_{z}$} & 1.54 \\
\hline \multicolumn{4}{|r|}{ Systematic error $\delta$} & 0.16 \\
\hline
\end{tabular}

Table 3

The effect of changes in the flow rate on the robustness values

\begin{tabular}{|c|c|c|c|c|c|c|}
\hline $\begin{array}{c}\text { The thymol } \\
\text { content, } \mu \mathrm{g} / \mathrm{mL}\end{array}$ & $\begin{array}{c}\text { The flow rate, } \\
\mathrm{mL} / \mathrm{min}\end{array}$ & $\begin{array}{l}\text { The retention } \\
\text { time, } \min \end{array}$ & The peak area & $\begin{array}{c}\text { The number } \\
\text { of theoretical } \\
\text { plates }\end{array}$ & $\begin{array}{c}\text { The symmetry } \\
\text { factor of the } \\
\text { peak }\end{array}$ & $\begin{array}{c}\text { The relative } \\
\text { standard } \\
\text { deviation for } \\
\text { the peak area, \% }\end{array}$ \\
\hline \multirow{9}{*}{4} & \multirow{3}{*}{0.8} & 15.756 & 34.774 & 1996 & 0.985 & \multirow{3}{*}{0.326} \\
\hline & & 15.734 & 35.420 & 2183 & 0.985 & \\
\hline & & 15.708 & 35.027 & 1984 & 0.994 & \\
\hline & \multirow{3}{*}{1.0} & 12.776 & 28.216 & 1992 & 1.043 & \multirow{3}{*}{0.299} \\
\hline & & 12.731 & 28.621 & 1957 & 0.963 & \\
\hline & & 12.675 & 28.800 & 1887 & 1.006 & \\
\hline & \multirow{3}{*}{1.2} & 10.626 & 24.775 & 1844 & 0.989 & \multirow{3}{*}{0.169} \\
\hline & & 10.709 & 24.443 & 1872 & 1,007 & \\
\hline & & 10.716 & 24.667 & 1863 & 0,989 & \\
\hline
\end{tabular}

Table 4

The effect of changes in the temperature on the robustness values

\begin{tabular}{|c|c|c|c|c|c|c|}
\hline $\begin{array}{c}\text { The thymol } \\
\text { content, } \mu \mathrm{g} / \mathrm{mL}\end{array}$ & $\begin{array}{c}\text { The } \\
\text { temperature, } \\
{ }^{\circ} \mathrm{C}\end{array}$ & $\begin{array}{l}\text { The retention } \\
\text { time, } \min \end{array}$ & The peak area & $\begin{array}{c}\text { The number } \\
\text { of theoretical } \\
\text { plates }\end{array}$ & $\begin{array}{c}\text { The symmetry } \\
\text { factor of the } \\
\text { peak }\end{array}$ & $\begin{array}{c}\text { The relative } \\
\text { standard } \\
\text { deviation for } \\
\text { the peak area, } \%\end{array}$ \\
\hline \multirow{9}{*}{4} & \multirow{3}{*}{27} & 14.078 & 30.216 & 1923 & 0.961 & \multirow{3}{*}{0.220} \\
\hline & & 14.016 & 30.338 & 1897 & 0.986 & \\
\hline & & 14.001 & 30.644 & 1812 & 1.004 & \\
\hline & \multirow{3}{*}{30} & 13.370 & 29.998 & 1939 & 0.984 & \multirow{3}{*}{0.323} \\
\hline & & 13.336 & 30.083 & 1909 & 1.000 & \\
\hline & & 13.372 & 30.154 & 1907 & 0.989 & \\
\hline & \multirow{3}{*}{33} & 13.192 & 30.939 & 1938 & 0.993 & \multirow{3}{*}{0.097} \\
\hline & & 13.098 & 30.992 & 1832 & 0.982 & \\
\hline & & 13.137 & 30.804 & 1963 & 0.981 & \\
\hline
\end{tabular}


The effect of changes in the mobile phase composition on the robustness values

\begin{tabular}{|c|c|c|c|c|c|c|}
\hline $\begin{array}{c}\text { The thymol } \\
\text { content, } \mu \mathrm{g} / \mathrm{mL}\end{array}$ & $\begin{array}{l}\text { The mobile } \\
\text { phase } \\
\text { composition }\end{array}$ & $\begin{array}{l}\text { The retention } \\
\text { time, } \min \end{array}$ & The peak area & $\begin{array}{c}\text { The number } \\
\text { of theoretical } \\
\text { plates }\end{array}$ & $\begin{array}{c}\text { The symmetry } \\
\text { factor of the } \\
\text { peak }\end{array}$ & $\begin{array}{c}\text { The relative } \\
\text { standard } \\
\text { deviation for } \\
\text { the peak area, } \%\end{array}$ \\
\hline \multirow{9}{*}{4} & \multirow{3}{*}{$47 / 53$} & 15.768 & 29.254 & 1916 & 1.003 & \multirow{3}{*}{0.277} \\
\hline & & 15.628 & 28.805 & 1895 & 1.005 & \\
\hline & & 15.885 & 28.748 & 1967 & 1.004 & \\
\hline & \multirow{3}{*}{$50 / 50$} & 12.478 & 29.917 & 1943 & 0.998 & \multirow{3}{*}{0.659} \\
\hline & & 12.467 & 29.869 & 1940 & 0.998 & \\
\hline & & 12.471 & 29.792 & 1941 & 1.016 & \\
\hline & \multirow{3}{*}{$53 / 47$} & 10.590 & 29.928 & 1831 & 1.004 & \multirow{3}{*}{0.085} \\
\hline & & 10.577 & 29.800 & 1827 & 1.022 & \\
\hline & & 10.716 & 29.960 & 1851 & 1.013 & \\
\hline
\end{tabular}

Robustness. The results of robustness verification (Tab. 3-5) has shown that small changes in the flow rate, temperature and the mobile phase composition do not affect the values of the symmetry factor of the principal peak, the relative standard deviation and the number of theoretical plates.

The results of studying stability indicate that the solution to be analysed may be chromatographed within 1 day without losses in accuracy and precision.

\section{CONCLUSIONS}

1. The method for quantitative determination of thymol (the main active component) in "Kalinol plus" syrup has been developed using HPLC.

2 . The validation characteristics of the method proposed (accuracy, precision, linearity, robustness, specificity, and stability) have been studied. According to the results the method can be recommended for using in the analysis of "Kalinol plus" syrup.

\section{REFERENCES}

1. Гризодуб А.И. Стандартизованные прочедуры валидаџии методик контроля качества лекарственных средств / Аналитическая химия в создании, стандартизации и контроле качества лекарственных средств: в 3-х т.; Под ред. чл.-кор. НАН Украины В.П.Георгиевского. - Х.: НТМТ, 2011. - Т. 3. - С. $934-1063$.

2. Alekseeva L.I. // Pharm. Chem. J. - 2009. - Vol. 43, №12. - P. 665-667.

3. Ceylan R., Zengin G., Uysal S. et al. // J. Enzyme Inhib. Med. Chem. - 2015. - Vol. 1. - P. 1-8.

4. ICH Harmonised Tripartite Guideline. Validation of Analytical Procedures: Text and Methodology Q2(R1). Geneva: ICH, 1995. - 13 p.

5. Kalinol plus //www.pharma.az.

6. Mancini E., Senatore F., Del Monte D. et al. // Molecules. - 2015. - Vol. 20, №7. - P. 12016-12028.

7. Marchese A., Orhan I.E., Daglia M. et al. // Food Chem. - 2016. - Vol. 210. - P. 402-414.

8. Nabavi S.M., Marchese A., Izadi M. et al. // Food Chem. - 2015. - Vol. 173. - P. 339-347.

9. Rodríguez-Solana R., Salgado J.M., Domínguez J.M. et al. // Phytochem. Anal. - 2015. - Vol. 26, №1. - P. 61-71.

10. Samani S.M., Moein M., Petramfar P. et al. // Curr. Drug Discov. Technol. - 2016. - Vol. 13, №2. - P. 77-83.

11. Technical Guide for the Elaboration of Monographs / European Pharmacopoeia; European Directorate for the Quality of Medicines \& HealthCare. - 6-th ed. - Strasbourg: Council of Europe, 2011. - 72 p.

\section{РОЗРОБКА І ВИЗНАЧЕННЯ ВАЛІДАЦІЙНИХ ПАРАМЕТРІВ ВЕРХ-МЕТОДИКИ КІЛЬКІСНОГО ВИЗНАЧЕННЯ ТИМОЛУ В СИРОПІ «КАЛИНОЛ ПЛЮС» \\ Т.А.Сулейманов, Е.З.Балаєва, Е.Ю.Ахмедов \\ Ключові слова: валідація; сироп «Калинол плюс»; тимол; ВЕРХ}

Розроблено BEPX-методику кількісного визначення тимолу у комбінованому лікарському препараті - сиропі «Калинол плюс» виробництва «ТОВ Азерфарм», до складу якого входить екстракт чебрецю, цукровий сироп, калію бромід та 80\% етанол. Були знайдені оптимальні умови кількісного визначення тимолу в сиропі «Калинол плюс» - швидкість потоку (1 мл/хв), температура (30 C), об’єм введеної проби (10 мкл), довжина хвилі детектора (274 нм), тип нерухомої фази (Zorbax SB-C18 Ø4,6’250 мм, 5 мкм) та склад рухомої фрази (суміш води та ацетонітрилу (50:50) в режимі ізократичного елюювання), маса зразка для аналізу (1,0 г), час аналізу (15 хв) - шляхом проведення аналізу за різних умов. Встановлено, що пік аналіту на 
хроматограмі добре розділяється з піками допоміжних речовин та інших компонентів активної субстанції. Вивчені валідаційні параметри запропонованої методики. Зәідно з отриманими результатами розроблена процедура характеризується прийнятною лінійністю $(b=1,037$, $\left.a=-5,587, R S D_{0}=1,715, R_{c}=0,9959\right)$, правильністю $(\delta=0,16)$ та збіжністю $\left(\Delta_{z}=1,54\right)$ у рамках діапазону застосування (70-130\% від номінального вмісту). Невеликі зміни швидкості потоку (від 0,8 мл/хв до 1,2 мл/хв), температури (від $27^{\circ} \mathrm{C}$ до $33^{\circ} \mathrm{C}$ ) і складу рухомої фрази (співвідношення від (47:53) (47:53)) невагомо впливають на значення коефіцієнта симетрії піку, відносного стандартного відхилення і числа теоретичних тарілок. Результати вивчення стабільності свідчать про те, що аналізований розчин можна хроматографувати протягом 1 дня без погіршення правильності та прецизійності. За результатами досліджень методика може бути рекомендована для використання в аналізі сиропу «Калинол плюс».

\section{РАЗРАБОТКА И ОПРЕДЕЛЕНИЕ ВАЛИДАЦИОННЫХ ПАРАМЕТРОВ ВЭЖХ-МЕТОДИКИ КОЛИЧЕСТВЕННОГО ОПРЕДЕЛЕНИЯ ТИМОЛА В СИРОПЕ «КАЛИНОЛ ПЛЮС Т.А.Сулейманов, Э.З.Балаева, Э.Ю.Ахмедов}

Ключевые слова: валидация; сироп «Калинол плюс»; тимол; ВЭЖХ

Разработана ВЭЖХ-методика количественного определения тимола для комбинированного лекарственного препарата - сиропа «Калинол плюс» производства «ООО Азерфрарм», в состав которого входит экстракт чабреца, сахарный сироп, калия бромид и $80 \%$ этанол. Были найдены оптимальные условия количественного определения тимола в сиропе «Калинол плюс» - скорость потока (1 мл/мин), температура (30 $\left.{ }^{\circ} \mathrm{C}\right)$, объем вводимой пробы (10 мкл), длина волны детектора (274 нм), тип неподвижной фразы (Zorbax SB-C18 Ø4,6’250 мм, 5 мкм) и состав подвижной фразы (смесь воды и ацетонитрила (50:50) в режиме изократического элюирования), масса образца для анализа (1,0 2), время анализа (15 мин) - путем проведения анализа в различных условиях. Установлено, что пик аналита на хроматограмме хорошо разделяется с пиками вспомогательных веществ и других компонентов активной субстанции. Изучены валидационные параметры предложенной методики. Согласно полученным результатам разработанная процедура характеризуется приемлемой линейностью ( $\left.b=1,037, a=-5,587, R S D_{0}=1,715, R_{c}=0,9959\right)$, правильностью $(\delta=0,16)$ и сходимостью $\left(\Delta_{z}=1,54\right)$ в рамках диапазона применения (70-130\% от номинального содержания). Небольшие изменения скорости потока (от 0, 8 мл/мин до 1,2 мл/мин), температуры (от $27^{\circ} \mathrm{C}$ до $\left.33^{\circ} \mathrm{C}\right)$ и состава подвижной фразы (соотношение от (47:53) до (47:53)) незначительно влияют на значения коэффрициента симметрии пика, относительного стандартного отклонения и числа теоретических тарелок. Результаты изучения стабильности свидетельствуют о том, что анализируемый раствор можно хроматографировать в течение 1 дня без ухудшения правильности и прецизионности. По результатам исследований методика может быть рекомендована для использования в анализе сиропа «Калинол плюс». 